\title{
Evaluasi Usability Website Shopee Menggunakan System Usability Scale (SUS)
}

\author{
Firman Galuh Sembodo ${ }^{1 *}$, Gita Fadila Fitriana ${ }^{2 *}$, Novian Adi Prasetyo ${ }^{3 * *}$ \\ * Program Studi S1 Rekayasa Perangkat Lunak, Institut Teknologi Telkom Purwokerto \\ ** Program Studi S1 Informatika, Institut Teknologi Telkom Purwokerto \\ 17104007@ittelkom-pwt.ac.id ${ }^{1}$, gita@ittelkom-pwt.ac.id ${ }^{2}$, novian@ittelkom-pwt.ac.id ${ }^{3}$
}

\section{Article Info \\ Article history: \\ Received 2021-08-23 \\ Revised 2021-10-26 \\ Accepted 2021-11-1}

\section{Keyword:}

User,

Shopee,

Usability,

Quality,

Website

\begin{abstract}
The progress of information technology is currently growing rapidly. Technology related to the internet is often a solution to most of the problems in existing needs, especially those related to the effectiveness and efficiency of activities and procedures. In this final project, the author discusses websites in the business field, namely e-commerce websites. In this study, the authors chose one of the most popular e-commerce websites in Indonesia this year, namely the shopee website, a website that not only offers products but also puts forward the appearance of the Shopee website which must always be considered because it is the main factor to increase customer purchases. In this study, the quality of the web that will be measured by users, especially for consumers, is based on measuring the quality of the website using the System Usability Scale (SUS). Evaluation of the shopee website is the first step to measure the level of usability on the website. Usability evaluation on the website is carried out to collect opinions from various respondents regarding the functionality of the website. In this study, the results obtained from the calculation of the average usability of the shopee website of 67.08 so that it can be said that the usability of the shopee website on product purchases has entered the OK category.
\end{abstract}

This is an open access article under the CC-BY-SA license.

\section{Pendahuluan}

Kemajuan teknologi informasi saat ini berkembang pesat. Teknologi yang berkaitan dengan internet seringkali menjadi sebuah solusi bagi sebagian besar permasalahan pada kebutuhan yang ada terutama yang berkaitan dengan efektivitas dan efisiensi dari kegiatan maupun prosedur [1]

Indonesia mengalami perkembangan pesat di bidang $e$ commerce saat ini dibandingkan dengan beberapa tahun sebelumnya. Di Indonesia, berbelanja secara online telah menjadi pilihan banyak pihak untuk memperoleh barang. Penerapan teknologi komunikasi informasi yang bisa digunakan untuk menunjang sistem perdagangan online adalah E-commerce. E-commerce adalah penjualan yang dilakukan melalui media elektronik. Pertumbuhan Ecommerce yang terus meningkat di Indonseia membuat Shopee ikut meramaikan industri ini. Banyaknya marketplace yang saat ini menguasai pasar Indonesia seperti Tokopedia, Bukalapak, Shopee, Lazada, Blibli, JD.Id dan lainnya.
Dibanding dengan E-commerce yang lain shopee memiliki pangsa pasar yang luas. Pada tahun 2017 Shopee menduduki peringkat pertama di Indonesia sebagai situs toko online yang paling banyak dikunjungi. Data iPrice menunjukkan jumlah pengunjung shopee selama tiga tahun terakhir terus mengalami peningkatan sejak Quartal pertama 2019. Shopee menduduki peringkat pertama sebagai top of mind brand. Terpilihnya Shopee sebagai marketplace terpopuler di mata masyarakat menunjukkan bahwa Shopee memiliki citra perusahaan yang baik. Platform marketplace Shopee memiliki dua bentuk aplikasi yang di gunakan yaitu aplikasi berbasis mobile dan website. Fleksibilitas Smartphone yang dapat menunjang kebutuhan manusia saat ini mengakibatkan masyarakat yang telah memiliki perilaku belanja online mulai beralih dari website ke mobile. Website adalah kerangka kerja yang dapat digunakan untuk menyebarkan data, sehingga website di era inovatif saat ini banyak digunakan untuk kehidupan sehari-hari. Pada penelitian ini penulis memilih salah satu website e-commerce terpopuler di Indonesia tahun 
ini yaitu website Shopee, sebuah website yang bukan hanya menawarkan produk tetapi juga mengedepankan tampilan dari website Shopee yang harus selalu diperhatikan karena menjadi faktor utama untuk meningkatkan pembelian pelanggan. Pengguna atau pelanggan website Shopee di Indonesia sangatlah banyak sehingga memunculkan banyak persepsi tentang website Shopee baik dari kualitas website atau usabilitas [2].

Kualitas dari suatu website e-commerce dapat mempengaruhi jumlah pengguna yang memilih untuk berbelanja online pada website e-commerce, untuk mengetahui kualitas situs yang tinggi dan rendah yang ditentukan oleh standar pengguna[3]. Pengukuran kualitas pada website khususnya e-commerce dapat dilakukan menggunakan pengukuran nilai usability pada website tersebut [2].

Usability merupakan suatu pengalaman pengguna dalam berinteraksi dengan aplikasi atau situs web sampai pengguna dapat mengoperasikannya dengan efektif dan cepat menurut Nielsen [4]. SUS merupakan salah satu metode uji pengguna yang menyediakan alat ukur yang "quick and dirty" yang dapat diandalkan. Metode ini diperkenalkan oleh John Brooke pada tahun 1986 yang dapat digunakan untuk melakukan evaluasi berbagai jenis produk ataupun layanan[5]. Dalam penelitian ini, kualitas web yang akan diukur oleh pengguna khususnya untuk konsumen dengan didasari oleh pengukuran kualitas website menggunakan System Usability Scale (SUS) [5]. Evaluasi usability pada website dilakukan untuk mengumpulkan anggapan dari responden yang berbeda mengenai kegunaan website[4]. Sesuai dengan permasalahan tersebut diperlukan adanya evaluasi usability pada website Shopee agar dapat mengetahui kelayakan sistem apakah website Shopee mudah digunakan oleh pengguna, seberapa cepat pengguna dapat dengan mudah memahami dan menggunakan website, apakah pengguna masih banyak mengalami kendala atau kesusahan dalam menggunakan website tersebut [5]. Pengujian usability dapat dilakukan pada perangkat lunak yang kecil maupun besar dan multiplatform seperti berbasis web, dekstop, maupun mobile. Fokus dari pengujian usability adalah pengguna mendapatkan kemudahan dalam menggunakan perangkat lunak [6].

Untuk menilai apakah aplikasi yang disediakan telah memiliki nilai kebergunaan bagi pengguna maka perlu dilakukan evaluasi pandangan pengguna untuk mengukur tingkat kebergunaan. Teknik pengujian usability dapat digunakan dalam melakukan evaluasi berdasarkan pandangan pengguna, karena usability merupakan teknik pengujian yang dilakukan sesuai dengan pengalaman pengguna terhadap sebuah sistem. Pengujian dengan teknik usability berfokus pada penilaian tingkat kebergunaan sistem yang disediakan [7]. Metode pengujian usability yang digunakan dalam penelitian ini yaitu metode System Usability Scale (SUS). System usability scale sendiri memiliki kelebihan yaitu: “(1) proses evaluasi lebih mudah dimengerti oleh responden, (2) menggambarkan hasil yang maksimal dengan melibatkan sample yang sedikit, dan (3) dapat dilihat dengan jelas antara aplikasi yang dapat dan tidak dapat digunakan" [7]. Menurut Sauro SUS juga memiliki instrumen yang jelas pada cara perhitungan untuk melakukan evaluasi sebuah aplikasi. Dengan demikian nilai evaluasi yang dihasilkan memiliki nilai kebenaran dan dapat dipertanggungjawabkan [8].

\section{METODE}

\section{A. Identifikasi Masalah}

Identifikasi masalah adalah fase permulaan dari penguasaan masalah dimana suatu objek tertentu dalam situasi tertentu yang dapat dianggap sebagai suatu masalah. Pada tahap ini penulis mengenali masalah dalam kerangka yang sedang berjalan untuk menemukan kebutuhan yang akan dipenuhi. Dengan memperhatikan, menelusuri dan menilai.tentang website shopee.co.id.

\section{B. Studi Literatur}

Studi Literatur merupakan pendekatan untuk mengatasi masalah dengan mengikuti sumber-sumber komposisi yang telah dibuat sebelumnya. Pada tahap ini penulis melakukan pencarian, khususnya pencarian data dengan membaca dan kemudian mengambil informasi dari berbagai buku, buku harian, atau tujuan di web yang sesuai dengan masalah yang akan digunakan sebagai eksplorasi sebagai alasan untuk mengarahkan penelitian.

\section{Pengukuran Instrumen (Kuesioner)}

Pada tahap ini penulis melakukan Pengukuran Instrumen atau biasa disebut Kuesioner dengan cara melakukan penyusunan kuesioner System Usability Scale (SUS) yang memuat aspek learnability, efficiency, memorability, errorsdan satisfaction dengan cara pengukuran berupa angka dengan skala 1-5. Kemudian setelah itu penulis melakukan penyebaran kuesioner secara langsung terhadap responden pengguna website shopee.co.id. Dalam penelitian ini diperlukan 30 orang responden kisaran umur 17-30 tahun untuk pengumpulan data menggunakan Google Form [15]. Pengujian data ini dilakukan dengan cara mengolah hasil kuesioner yang telah diisi oleh responden dengan bantuan 10 pertanyaan dari kuesioner System Usability Scale dibantu dengan One Sample $T$ - Test untuk melakukan pengujian hipotesis.

\section{Analisis Data}

Pada tahap ini yaitu menganalisis data yang telah diolah dengan menunjukan hasil hipotesis dari aspek variabel dengan menggunakan System Usability Scale (SUS). Analisis data tersebut menunjukan pengaruh positif antar variabel yang lain sehingga dapat ditarik kesimpulan terhadap hasil analisis dari penelitian ini.

Penelitian ini melakukan evaluasi usability website shopee menggunakan metode system usability scale (SUS) yaitu pengukuran dari segi efesiensi. Pengumpulan data dilakukan oleh pengguna website shopee yang melakukan 
pembelian produk berjumlah 30 responden dengan menggunakan google form. System Usability Scale (SUS) merupakan metode evaluasi kegunaan yang dapat memberikan hasil yang memadai berdasarkan pertimbangan jumlah sampel yang kecil, waktu dan biaya [11]. Perhitungan tersebut menghasilkan strategi SUS yang akan diubah menjadi suatu nilai yang dapat digunakan sebagai bahan pertimbangan untuk memutuskan apakah suatu aplikasi dapat diterapkan atau tidak. SUS juga telah digunakan untuk menentukan sejauh mana faktor pengalaman menggunakan suatu item akan benar-benar ingin memengaruhi klien dalam memberikan penghargaan SUS yang tinggi. Oleh karena itu, hasil penelitian ini menunjukkan bahwa nilai SUS yang lebih tinggi dan lebih produktif daripada klien situs yang tidak berpengalaman.

System Usability Scale (SUS) merupakan kuesioner yang dapat digunakan untuk mengukur usability sistem komputer menurut sudut pandang subyektif pengguna yang terdiri dari 10 item pertanyaan (Brooke, 1996). Dalam melakukan perhitungan SUS menggunakan lima skala Likert. Responden diminta untuk memberikan 10 pernyataan SUS sesuai dengan penilaian subjektifnya. Menurut Brooke (2013), kuesioner SUS dapat digunakan untuk mengukur tingkat kepuasan pengguna untuk mengukur tingkat kepuasan pengguna pada suatu produk[12]. Setiap item pernyataan memiliki skor kontribusi setiap skor akan berkisar antara 0 hingga 4 . Untuk item 1,3,5,7 dan 9 skor kontribusinya adalah posisi skala dikurangi 1. Untuk item 2,4,6,8 dan 10, skor kontribusinya adalah 5 dikurangi posisi skala. Kemudian kalikan jumlah skor SUS berkisar dari 0 hingga 100[13].

Komponen pertanyaan dari SUS yang akan digunakan mengacu pada instrument [7]. Komponen pertanyaan SUS dapat dilihat pada Tabel I.

TABEL I

HASIL PERHITUNGAN KUESIONER SUS

\begin{tabular}{|c|l|}
\hline No & \multicolumn{1}{|c|}{ Komponen } \\
\hline 1 & Saya berpikir akan menggunakan sistem ini lagi. \\
\hline 2 & Saya merasa sistem ini rumit untuk digunakan. \\
\hline 3 & Saya merasa sistem ini mudah digunakan. \\
\hline 4 & $\begin{array}{l}\text { Saya membutuhkan bantuan dari orang lain atau teknisi } \\
\text { dalam menggunakan sistem ini. }\end{array}$ \\
\hline 5 & $\begin{array}{l}\text { Saya merasa fitur-fitur sistem ini berjalan } \\
\text { dengan semestinya. }\end{array}$ \\
\hline 6 & $\begin{array}{l}\text { Saya merasa ada banyak hal yang tidak konsisten (tidak } \\
\text { serasi pada sistem ini). }\end{array}$ \\
\hline 7 & $\begin{array}{l}\text { Saya merasa orang lain akan memahami cara } \\
\text { menggunakan sistem ini dengan cepat. }\end{array}$ \\
\hline 8 & Saya merasa sistem ini membingungkan. \\
\hline 9 & $\begin{array}{l}\text { Saya merasa tidak ada hambatan dalam menggunakan } \\
\text { sistem ini. }\end{array}$ \\
\hline 10 & $\begin{array}{l}\text { Saya perlu membiasakan diri terlebih dahulu sebelum } \\
\text { menggunakan sistem ini. }\end{array}$ \\
\hline
\end{tabular}

Pada Tabel II, merupakan Skor SUS, hasil dari pengolahan komponen pertanyaan SUS dari responden dapat dihitung untuk nilai rata-rata dari skor SUS berikut

TABEL III

SKOR SUS

\begin{tabular}{|c|c|c|}
\hline$>81$ & A & Excellent \\
\hline $68-81$ & B & Good \\
\hline 68 & C & OK/Fair \\
\hline $51-67$ & D & Poor \\
\hline$<51$ & F & Worst \\
\hline
\end{tabular}

Metode Usability System Usability Scale (SUS) karena dalam pemrosesan kuesioner SUS melakukan pengukuran usability yang "quick and right" (cepat dan tepat), yang dimana output yang dihasilkan oleh SUS berupa skor yang tampak mudah dipahami, dengan range dari 0 hingga 100 , dengan semakin besar skor SUS maka semakin baik kualitas usability [13].

Kemudian setelah itu penulis melakukan penyebaran kuesioner secara langsung terhadap responden pengguna website shopee.co.id. Dalam penelitian ini diperlukan 30 orang responden kisaran umur 17-30 tahun untuk pengumpulan data menggunakan Google Form. Pengujian data ini dilakukan dengan cara mengolah hasil kuesioner yang telah diisi oleh responden.

\section{E. Interpretasi Data dan Penarikan Kesimpulan}

Pada tahap ini yaitu memberikan interpretasi artinya memberikan arti yang lebih luas dari penemuan penelitian mencakup dua aspek yaitu menghubungkan hasil penelitian dengan penemuan penelitian yang lain dan menghasilkan suatu konsep yang bersifat menjelaskan. Kemudian dilakukan penarikan kesimpulan dengan pernyataan tentang hasil pengujian hipotesis untuk mengetahui hasil akhir yang diperoleh dari penelitian yang sedang dilakukan.

\section{Hipotesis Penelitian}

Pada tahap hipotesis yang dapat dijadikan sebagai acuan pada penelitian ini sebagai berikut:

H0: Rata - rata nilai usability website sama dengan 68

H1: Rata - rata nilai usability website tidak sama dengan 68

Berdasarkan rata - rata nilai usability website yang didapat dari hipotesa. Apabila nilai signifikansi kurang dari 0,05 maka H0 ditolak, sedangkan apabila nilai signifikansi lebih dari 0,05 maka H0 diterima. Hasil tersebut didapatkan dari perhitungan statistik dengan menggunakan One Sample $T-$ Test yang dibantu menggunakan SPSS [15]. 


\section{HASIL DAN PEMBAHASAN}

Pengujian dilakukan setelah responden selesai melakukan task yang sudah diberikan. Peneliti membagikan kuesioner SUS yang harus diisi responden, kemudian data tersebut diolah sehingga menghasilkan output yaitu pengujian usability dengan menggunakan metode System Usability Scale.

\section{A. Hasil Perhitungan Kuesioner SUS}

Pada analisis usability data yang diperoleh kemudian dikelompokkan dan dilakukan perhitungan untuk menentukan score usability website shopee yang diuji berkaitan dengan task pembelian produk berdasarkan kuesioner SUS. Peneliti menggunakan aturan perhitungan yaitu Setiap pernyataan memiliki score kontribusi. Setiap score kontribusi akan berkisar antara 0 sampai 4 . Untuk item 1,3,5,7,9 score kontribusinya adalah posisi skala dikurangi 1 . Untuk item 2,4,6,8,10 score kontribusinya adalah 5 dikurangi posisi skala. Kemudian kalikan jumlah score dengan 2.5 untuk mendapatkan nilai system usability, selanjutnya dijumlahkan dan dibagi dengan jumlah responden yaitu 30 responden. Berikut hasil score yang dapat dilihat pada Tabel III.

TABEL IIIII

HASIL PERHITUNGAN KUESIONER SUS

\begin{tabular}{|l|l|l|l|}
\hline Responden & Skor & Responden & Skor \\
\hline R1 & 67,5 & R16 & 75 \\
\hline R2 & 90 & R17 & 52,5 \\
\hline R3 & 77,5 & R18 & 77,5 \\
\hline R4 & 55 & R19 & 70 \\
\hline R5 & 75 & R20 & 57,5 \\
\hline R6 & 87,5 & R21 & 60 \\
\hline R7 & 85 & R22 & 70 \\
\hline R8 & 80 & R23 & 60 \\
\hline R9 & 50 & R24 & 75 \\
\hline R10 & 67,5 & R25 & 100 \\
\hline R11 & 57,5 & R26 & 52,5 \\
\hline R12 & 67,5 & R27 & 50 \\
\hline R13 & 75 & R28 & 50 \\
\hline R14 & 70 & R29 & 50 \\
\hline R15 & 57,5 & R30 & 50 \\
\hline Skor rata-rata & & 67,08 \\
\hline
\end{tabular}

Hasil perhitungan dari kuesioner diatas ini diperkuat dengan analisis uji one sample t-test. Sebelum analisis paired one sample t-test data dipastikan berdistribusi normal dengan dilakukan uji normalitas. Uji normalitas kepuasan pada kuesioner SUS website Shopee menggunakan uji normalitas Kolmogrov-Smirnov dan Shapiro-Walk[16].

\section{B. Uji Normalitas}

TABEL IV

UJI NORMALITAS SCORE SUS

\begin{tabular}{|l|l|l|l|l|l|l|}
\hline \multirow{2}{*}{} & \multicolumn{4}{|l|}{ Kolmogorov-Smirnov } & \multicolumn{2}{l|}{ Shapiro-Wilk } \\
\cline { 2 - 7 } & Statistic & df & Sig. & Statistic & df & Sig. \\
\hline Score & 0,131 & 30 & 0,198 & 0,936 & 30 & 0,071 \\
\hline
\end{tabular}

Berdasarkan Tabel IV nilai signifikansi kepuasan website Shopee pada uji normalitas Shapiro-Walk hasilnya sebesar 0,071 dimana hasil tersebut lebih besar dari 0,05 sehingga dapat disimpulkan bahwa data kepuasan berdistribusi normal[17].

Setelah dilakukan uji normalitas, selanjutnya dilakukan uji one sample statistics. Berikut merupakan hasil uji one sample satatistics usability website Shopee yang dapat dilihat pada Tabel V.

\section{Uji One sample test}

Berdasarkan pada Tabel III menunjukan nilai statistik deskriptif, yaitu $\mathrm{N}=30$ artinya jumlah sample yang digunakan adalah 30 orang[18]. Mean sebesar 67,08 lalu ada Std. Deviation atau simpangan baku sebesar 13,66286 lalu Std Error Mean sebesar 2,49449. Kemudian setelah uji one sample statistics, selanjutnya adalah melakukan uji one sample t-test yang digunakan untuk mendapatkan hasil hipotesis penelitian, dimana hasil uji one sample t-test dapat dilihat pada Tabel VI.

TABEL V ONE SAMPLE STATISTICS

\begin{tabular}{|l|l|l|l|l|}
\hline & N & Mean & $\begin{array}{l}\text { Std. } \\
\text { Deviation }\end{array}$ & $\begin{array}{l}\text { Std. Error } \\
\text { Mean }\end{array}$ \\
\hline Score & 30 & 67,0833 & 13,66286 & 2,49449 \\
\hline
\end{tabular}

TABEL IVI

ONE SAMPLE T-TEST

\begin{tabular}{|l|l|l|}
\hline \multirow{2}{*}{ Score } & \multicolumn{2}{|c|}{ Test Value $=68$} \\
\cline { 2 - 3 } & $\mathrm{t}$ & $\mathrm{df}$ \\
\cline { 2 - 3 } & -.367 & 29 \\
\hline
\end{tabular}

\begin{tabular}{|l|l|l|l|l|}
\hline \multirow{2}{*}{} & \multicolumn{3}{|c|}{ Test Value $=68$} \\
\cline { 2 - 5 } & $\begin{array}{l}\text { Sig. (2- } \\
\text { tailed) }\end{array}$ & $\begin{array}{l}\text { Mean } \\
\text { Difference }\end{array}$ & \multicolumn{2}{|c|}{$\begin{array}{c}\text { 95\% Confidence } \\
\text { Interval of the } \\
\text { Difference }\end{array}$} \\
& & & \multicolumn{2}{|c|}{ Upper } \\
\cline { 3 - 5 } & & & Lower & U.1851 \\
\hline Score & .716 & -.91667 & \multicolumn{3}{|c}{} \\
\hline
\end{tabular}

Berdasarkan Tabel $\mathrm{V}$ dapat dilihat nilai signifikan yang diperoleh 0,716 dengan menggunakan value 68 dimana menunjukkan angka signifikan ini lebih besar dari 0,05 maka hipotesis penelitian diperoleh adalah $\mathrm{H} 0$ diterima oleh karena itu H1 ditolak dimana dapat di deskripsikan Rata - rata nilai usability website Shopee tidak sama dengan 68 atau lebih kecil dari 68[19]. Hasil ini sesuai dengan nilai rata - rata yang 
sudah diperoleh dari perhitungan kuesioner SUS dimana skor kepuasan pengguna 67,0833 .

\section{KESIMPULAN}

Berdasarkan penelitian yang telah dilakukan dapat diambil kesimpulan mengenai Evaluasi Usability Website Shopee Menggunakan System Usability Scale (SUS) didapatkan hasil berdasarkan pengujian data yang sudah diolah didapatkan nilai rata-rata usability website shopee memperoleh skor 67,0833 mengunjukan bahwa website shopee memiliki tingkat usability pada fitur pembelian produk sudah dalam kategori OK. Pada uji normalitas data yang didapat telah berdistribusi normal, sedangkan pada uji One sample T-Test menunjukan bahwa angka signifikan lebih besar dari 0,05 maka hipotesis penelitian diperoleh adalah $\mathrm{H} 0$ diterima oleh karena itu H1 ditolak dimana dapat dideskripsikan bahwa rata-rata nilai usability website Shopee tidak sama dengan 68 atau lebih kecil dari 68.

\section{DAFTAR PUSTAKa}

[1] M. A. Arga Kusumah, R. I. Rokhmawati, and F. Amalia, "Evaluasi Usability Pada Website E-commerce XYZ Dengan Menggunakan Metode Cognitive Walkthrough dan System Usability Scale (SUS)," Pengemb. Teknol. Inf. dan Ilmu Komput., vol. 3, no. 5, pp. 4340-4348, 2019.

[2] A. P. Ayudhitama and U. Pujianto, "Analisa Kualitas Dan Usability Berdasarkan Persepsi Pada Website Shopee," J. Inform. Polinema, vol. 6, no. 1, pp. 61-70, 2020, doi: 10.33795/jip.v6il.275.

[3] D. Irmawati, "Pemanfaatan E-Commerce Dalam Dunia Bisnis," Orasi Bisnis, vol. VI, no. November, pp. 95-112, 2011.

[4] Amin Dwi Purwati, "Evaluasi Usability Website Menggunakan System Usability Scale," Bina Darma Conf. Comput. Sci., vol. 2, no. 1, pp. 29-37, 2019, [Online]. Available:

http://jti.respati.ac.id/index.php/jurnaljti/article/view/213.

[5] A. W. Soejono, A. Setyanto, and A. F. Sofyan, "Evaluasi Usability Website UNRIYO Menggunakan System Usability Scale (Studi Kasus: Website UNRIYO)," J. Teknol. Inf., vol. XIII, no. 1, pp. 29-37, 2018, [Online]. Available:

http://jti.respati.ac.id/index.php/jurnaljti/article/view/213.

[6] B. Pudjoatmodjo and R. Wijaya, "Tes Kegunaan (Usability Testing) Pada Aplikasi Kepegawaian Dengan Menggunakan System Usability Scale," Semin. Nas. Teknol. Inf. dan Multimed. 2016, pp. 37-42, 2016.

[7] S. Suyanto and U. Ependi, "Pengujian Usability dengan Teknik System Usability Scale pada Test Engine Try Out Sertifikasi," MATRIK J. Manajemen, Tek. Inform. dan Rekayasa Komput., vol. 19, no. 1, pp. 62-69, 2019, doi: 10.30812/matrik.v19i1.503.

[8] U. Ependi, A. Putra, and F. Panjaitan, "Evaluasi tingkat kebergunaan aplikasi administrasi penduduk menggunakan teknik system usability scale," Regist. J. Ilm. Teknol. Sist. Inf., vol. 5, no. 1, pp. 63-76, 2019, doi: 10.26594/register.v5i1.1412.

[9] M. A. Zulhijdi, R. I. Rokhmawati, and N. Y. Setiawan, "Evaluasi Usability Situs Web Snapixa dengan menggunakan Metode Usability Testing dan System Usability Scale," J. Pengemb. Teknol. Inf. dan Ilmu Komput., vol. 3, no. 10, pp. 9348-9356, 2019.

[10] A. Nioga, K. C. Brata, and L. Fanani, "Evaluasi Usability Aplikasi Mobile KAI Access Menggunakan Metode System Usability Scale (SUS) Dan Discovery Prototyping (Studi Kasus PT KAI)," J-PTIIK J. Pengemb. Teknol. Inf. dan Ilmu Komput., vol. 3, no. 2, pp. 1396-1402, 2019, [Online]. Available: $\quad$ http://j-ptiik.ub.ac.id/index.php/jptiik/article/view/4384.

[11] Kharis, P. I. Santosa, and W. W. Winarno, "Evaluasi Usability Pada Sistem Informasi Pasar Kerja Menggunakan System Usablity Scale (SUS)," Pros. Semin. Nas. Sains Dan Teknol. 10 2019, vol. X, pp. 240-245, 2019.

[12] Ika Aprilia, P. I. Nugroho, and R. Ferdiana, "Pengujian Usability Website Menggunakan System Usability Scale," J. IPTEKKOM J. Ilmu Pengetah. Teknol. Inf., vol. 17, no. 1, p. 31, 2015, doi: 10.33164/iptekkom.17.1.2015.31-38.

[13] A. L. Yuliati and C. I. Setiawati, "Quality Analysis of Shopee Website by Using Importance Performance Analysis Approach," vol. Vol.65, pp. 585-587, 2019, doi: 10.2991/icebef-18.2019.125.

[14] J. R. Lewis, "The System Usability Scale: Past, Present, and Future," Int. J. Hum. Comput. Interact., vol. 34, no. 7, pp. 577-590, 2018, doi: 10.1080/10447318.2018.1455307.

[15] A. A. Jiwa Permana, "Usability Testing Pada Website ECommerce Menggunakan Metode System Usability Scale (Sus) (Studi Kasus : Umkmbuleleng.Com)," JST (Jurnal Sains dan Teknol., vol. 8, no. 2, p. 149, 2019, doi: 10.23887/jst-undiksha.v8i2.22858.

[16] S. Suardi, "Pengaruh Kepuasan Kerja Terhadap Pegawai PT Bank Mandiri, Tbk Kantor Cabang Pontianak," Business, Econ. Entrep., vol. 1, no. 2, pp. 9-19, 2019, doi: 10.46229/b.e.e..v1i2.124.

[17] R. Kariadinata, Dasar-Dasar Statistik Penelitian. 2015.

[18] R. Alroobaea and P. J. Mayhew, "How many participants are really enough for usability studies?," Proc. 2014 Sci. Inf. Conf. SAI 2014, pp. 48-56, 2014, doi: 10.1109/SAI.2014.6918171.

[19] P. Jeff Sauro, "5 Ways To Interpret a Sus," Measuringu, 2018. https://measuringu.com/interpret-sus-score/. 